Theories \& Applications, the International Edition

Printed Version: (ISSN 2090-5262)

Online Version: (ISSN 2090-5270)

July 2012, Volume 2, No. 2 Pages (105 - 114)

\title{
Effect of Movement Education Program on Learning Some Numerical and Engineering Skills and Social Interaction for Preschool Stage Children
}

Hany Mohamed Fathy Ali*

\begin{abstract}
:
Movement education provides the educational situation that creates freedom, creation and expression throughout the child's tries to offer personal alternatives and solutions without concerning failure. It is considered one of the best educational styles that aims at learning and training children in different educational stages especially the preschool stage. It provides creative experience as well as it helps children to develop their understanding towards the others' thoughts and feelings. Throughout movement experiences, thinking process may be aroused and such experiences help in enriching positive social values and processes for these children. As a result, the goal of this research is to recognize the effect of movement education program on learning some numerical and engineering skills and social interaction for children of preschool stage. The researcher has used the experimental curriculum by designing two groups: controlling and experimental. Each consists of (30) male and female children among kindergarten children in Nasser Primary School in Aga, Dakahlia Governorate. One of the important results is that the proposed program, which has been applied on the experimental group in learning some numerical and engineering skills and developing the social interaction for sample children of the research, has contributed in movement education. Applying such program was one of the recommendations for its great effect on learning some numerical and engineering skills, developing social interaction for preschool children, and taking care of movement activities by using exploring method for its great effect on learning.
\end{abstract}

\section{Introduction:}

C hildhood is one of growth stages in humans' life, so taking care of such stage and its activities is considered one of the important indicators of society progress and welfare as it is one of the richest educational stages in forming characteristics. It is an educational stage in which education takes place and paves the way for the future educational process. So, it is considered the onset of the educational process as obtained experiences by the child in kindergarten cannot be provided similarly outside such place in which achieved goals inside this place affects his/her behavior greatly physically, psychologically, cognitively, and socially. It is a crucial stage in forming basic characteristics and the attitude of physical,

* Lecturer, Department of Curricula and Teaching Methods, Faculty of Physical Education, Mansoura University, Egypt. movement, muscular, cognitive, linguistic, social, emotional, aesthetic, and skillful growth (Abd El Fattah, 1994; Kenawy, 2004; Alshamary, 2005; Ahmed, 2006; Haikal, 2010).

Preschool educational stage is the perfect stage for education as the child is flexible for change and to absorb educational experiences. Basic stage is considered the natural preliminary and starting point for the primary stage as it is a strong bridge for young child's transition from home to the atmosphere of primary school that includes various activities, school subjects, social relationships, recreation programs, and new interests in the child's world in preschool period (Ahmed, 1994; Saber, 2007).

Movement education is one of the best educational methods that aims at learning and training children in different educational stages. Movement education style copes up with the stages of movement development and physical 
growth under which children explore during learning and mastering various movements to consider his/her physical movement, abilities and potentials. This process takes place without focusing on movement result as a basic educational process, exploration and creation to reach the best methods for the movement performance and solving movement problems in proportion with individual abilities, potentials and preparations of preschool children (Othman, 2008; Ben \& Scholastica, El Mosherafy, 2009).

We have to take care of such important age in which physical education contributes in learning process and movement, psychological, and social development. Also, it submits to methodology on both theoretical and applied levels according to specific objectives and purposes of such age as a focal point (Mohamed, 2004; El Mosherafy, 2009).

The use of movement activity program led to the improvement of study skills (Arabic mathematics) concerning remembering, understanding and applying. The same has been reached by Nader Abbass concerning school skills of English language and mathematics. Alan also emphasized the positive relation between movement skill and cognitive learning in mathematics, writing, reading, and language (Al-Kholy, 1996).

Learning by movement exploration has a special importance for young children who need to understand the world around them and to form concepts about this world by interacting directly with objects, observing and exploring their contents. Throughout interaction with nature, the child finds out that different objects may come up with different shapes: circular, square, or triangular. Movement exploration urges the child to create, excel and think to get the information by themselves. Such process gives children self-confidence, and encourages them to understand and develop movement. Moreover, it gives them the opportunity to explore their abilities and potentials (Al-Nashef, 1997; Rabei, 2000).

Playing contributes in developing social interaction and emotional maturity for the child. It is the basis of social relations among children and without playing with the others, the child becomes selfish, dominating, narrow-minded, and not loved by the others. Oppositely, if the child uses to play with the others, s/he learns how to give and receive, gets rid of selfcentralization, and learns how to exchange roles. Throughout giving and receiving, the child learns how to accept deaf gracefully as well as gain, and s/he is affected greatly by interaction process inside the society more than adults. Such social interaction takes place throughout the child's participation in social activities with mates and family. Such process becomes clear at the end of age of four and the beginning of age of five in the light of cooperation, competition, loyalty, solidarity, teamwork, and matches (Elsayed \& Abd El Rahman, 1999; Sherif 2001; Othman, 2011).

\section{Previous Studies:}

Othman's study (1997) was conducted to obtain, improve, and develop linguistic and numerical concepts of (3 to 4-year-old) children concerning movement games. One of the most important results was that movement games have a positive role in developing and obtaining linguistic and numerical concepts.

Erk's study (1999) aimed at recognizing the effectiveness of movement development program for preschool children.

Mohamed's study (2002) aimed at recognizing the effectiveness of movement education lesson on learning both Arabic and English languages. One of the most important results was a progression in learning level for the experimental group (KG2) that was taught Arabic and English by using the new method.

Mohamed's study (2004) aimed at revealing the effect of movement games and social games programs (movement games + social games) in developing social interaction for (5-6 year-old) kindergarten children. One of the most important results was that used programs contributed in developing social interaction for (5-6 year-old) kindergarten children.

Maria (2005) conducted another study to recognize elements that affect the curricula introduced to preschool children and their effects on basic movement skills. One of the most important results was that the study reached the importance of teaching and 
designing curricula that depend on basic movement skills.

Elsyaed (2007) designed an educational program by using movement exploring activities on preschool children to recognize the effect of the proposed program in numerical and engineering skills. The most important results were that the exploring method was better than traditional learning methods represented in the verbal explanation and performing a model from the teacher and the learner. Also, movement games have a positive effect on getting preschool child numerical and engineering skills.

Dawoud (2008) designed a program that depends on songs and chants to develop social interaction of kindergarten child. The most important results were that there are statistically significant differences on the (0.05) level between ranks average and experimental grades of the group in both pre and post evaluations on the social interaction scale.

\section{Study Problem:}

Teachers of kindergarten meet a lot of difficulties in dealing with such age because they lack modern educational techniques and programs to be used in teaching children. They depend on the traditional methods that lead to the absence of classroom interaction and lack of children's contributions in the educational situations they encounter. Since modern educational attitudes focus on abandoning the traditional methods that do not suit the nature and characteristics of such age, it has become a necessity to design educational programs to put the psychological basis of such age into consideration. Such basis is represented in the children's interest in playing and in physical activity that helps the child to be more interested and active in educational situations. Most academic references mention that playing is the basis of learning and the child's movement is the real starting point that all learning activities introduced to the kindergarten child focus on. For the importance of movement education for preschool child, a lot of referential studies, such as studies of both Othman (1997) and Mohamed (2004), have recommended to take care of movement games to make it the main theme of learning in preschool stage and movement activity by using learning method of exploration for its effective impact in learning as referred to in studies of Rabei (2000), Elsayed (2006), and Elsayed (2007).

In this respect, to the knowledge of the researcher, reviewing results and recommendations of many previous researches and studies in the field of movement education and kindergarten, such as studies of Ahmed (1994), Sherif (2001), Othman (2001), Mohamed (2004), Mohamed (2002), Elsayed (2007), Ohuruogu Ben, Orji Scholastica (2008), and Haikal (2010), that discuss the effect of designing movement education programs for teaching child and his/her use of movement as a means not an end and his/her use of the body to acquire knowledge about him/herself and about the world around, the researcher did not find any other studies that discuss learning some numerical and engineering skills, and social interaction throughout movement education program for children especially in the preschool stage (from 5 to 6 years old). The researcher believed that proposing a program may have a positive effect on children of kindergarten later to learn some numerical and engineering skills and to develop their social interaction. Hence, the idea of this research has arisen to discuss the effect of movement education program on learning some numerical and engineering skills and the social interaction of preschool (5-6year-old) children.

\section{Research Goals:}

The research aims at recognizing the effect of movement educational programs on learning some numerical and engineering skills and social interaction of preschool children throughout recognizing:

1. Designing a movement educational program for (5- 6 year old) preschool children.

2. The effect of the suggested program on learning some numerical and engineering skills and social interaction for preschool children.

3. Difference range in the effect of movement education program and the traditional program for preschool children. 


\section{Research Hypotheses:}

1. There are statistically significant differences between pre and post evaluations in learning some numerical and engineering skills and social interaction for preschool children in favor of post evaluation.

2. There are statistically significant differences between pre and post evaluations for the controlling group in learning some numerical and engineering skills and social interaction for preschool children in favor of post evaluation.

3. There are statistically significant differences between pre and post evaluations for both the experimental and controlling groups in learning some numerical and engineering skills and social interaction for preschool children in favor of the experimental group.

\section{Study Tools:}

1. Tests and Measurements of Growth Rate: Age, length, and weight.

2. Tests Used: Draw-a-Man Test of Goodenough-Harris (Appendix 2), the social interaction scale (economic - cultural) (Appendix 3), tests of numerical and engineering skills (Appendix 4), and preschool social interaction tests (Appendix 5).

3. Movement Education Program: Prepared by the Researcher (Appendix 7)

When setting the movement education program, the researcher reviewed all specialized academic references and the previous studies that discussed preschool stage children programs. The researcher put into consideration the suitability of the program for age (ages 5-6), interests, needs, and abilities to engage children enthusiastically and seriously in such program. To make sure of the program validity and suitability for children of this stage, the research goals and the characteristics of the children of the research sample (Appendices 6 and 7), the content of the program was displayed before a group of 5 specialized experts in programs and teaching methods who have experience in the field of childhood in the faculties of Education, Physical Education, and Kindergarten. The program consisted of multiple activities (basic movement skills, small games, free movement activities, movement rhythmic songs, simple recreational games, movement stories, and system exercises) and they were distributed in lessons. Time of program application took 2 months (8 weeks): 3 lessons a week / 35 minutes for each lesson.

\section{Study Methodology:}

To achieve the research goals and test hypotheses, the researcher uses the experimental methodology as it suits the research nature. Both controlling and experimental groups were used. Such methodology is worthwhile as it depends on elaborating the study hypotheses according to the used experimental design, understanding and elaborating the reasons of the effectiveness achieved the proposed program.

\section{Sample Selection / Study Community:}

The study community is represented by preschool children in the kindergarten of Nasser Primary School in Aga, Dakahlia Governorate in the academic year 2011/2012. They are 145 male and female children. Randomly selected, the sample consisted of 60 male and female children who form $42.37 \%$ of the research community. They were divided into two groups: experimental and controlling; each consisted of 30 male and female children with selecting 20 children from the original community and outside the basic sample to conduct a pilot study. The total research sample was 80 male and female children.

\section{Pilot Study:}

A pilot study was conducted on (20) males and female children from the same research society and outside the sample under discussion to recognize the following:

- Suitability range of movement education program contents for the children's level and movement abilities.

- Validity of devices and tools used in the program.

- Specifying the suitable place for executing the program. 
- Specifying timing allocated for the content of the lesson (preliminary - basic - final).

Pilot study results proved the program validity and its content suitability to be applied on kindergarten children. Also, they showed the validity of all program tools and devices and timing of the lesson parts (35 minutes): preliminary (5 minutes) - basic (25 minutes) final (5 minutes).

\section{Study Results:}

Table (1)

Differences Significance between Pre and Post Evaluations of the Experimental Group inside Variables Under Discussion

$$
S=30
$$

\begin{tabular}{|c|c|c|c|c|c|c|}
\hline \multirow{2}{*}{ Variables } & \multicolumn{2}{c|}{ Pre Evaluation } & \multicolumn{2}{c|}{ Post Evaluation } & \multirow{2}{*}{$\begin{array}{c}\text { Calculated } \\
(\mathrm{T}) \text { Value }\end{array}$} \\
\cline { 3 - 7 } & Median & Deviation & Median & Deviation & $* 21.625$ \\
\hline \multirow{3}{*}{\begin{tabular}{c} 
Achievement $\begin{array}{c}\text { Test } \\
\text { Test }\end{array}$ \\
\cline { 2 - 7 }
\end{tabular}} & Numerical Skills & 4.300 & 1.393 & 8.567 & 1.382 & $* 19.528$ \\
\cline { 2 - 7 } & Engineering Sills & 3.567 & 1.478 & 7.467 & 1.852 & $* 30.071$ \\
\hline \multicolumn{2}{|c|}{ Social Interaction } & 7.867 & 1.943 & 16.033 & 2.205 & $* 5.135$ \\
\hline
\end{tabular}

(T) Value in the table at $0.05=1.682$

* Function

Table (1) shows the existence of statistically significant differences between pre and post evaluations in variables under discussion "numerical and engineering skills", and social interaction of the experimental group in favor of the post evaluation. Calculated (T) Value is bigger than (T) Table Value at the significance level 0.05 .

Table (2)

Differences Significance between Pre and Post Evaluations of the Controlling Group inside Variables Under Discussion

$S=30$

\begin{tabular}{|c|c|c|c|c|c|c|}
\hline \multirow{2}{*}{\multicolumn{2}{|c|}{ Variables }} & \multicolumn{2}{|c|}{ Pre Evaluation } & \multicolumn{2}{|c|}{ Post Evaluation } & \multirow{3}{*}{$\begin{array}{c}\begin{array}{c}\text { Calculated } \\
\text { (T) Value }\end{array} \\
* 6.728\end{array}$} \\
\hline & & Median & Deviation & Median & Deviation & \\
\hline \multirow{3}{*}{$\begin{array}{c}\text { Achievement } \\
\text { Test }\end{array}$} & Numerical Skills & 4.264 & 1.413 & 5.167 & 1.367 & \\
\hline & Engineering Sills & 3.600 & 1.499 & 2.867 & 1.358 & $* 4.333$ \\
\hline & Total Degree & 7.867 & 2.013 & 8.133 & 1.871 & $* 4.181$ \\
\hline \multicolumn{2}{|c|}{ Social Interaction } & 115.000 & 32.563 & 118.333 & 33.434 & $* 3.247$ \\
\hline
\end{tabular}

(T) Value in the table at $0.05=1.682$

Table (2) shows the existence of statistically significant differences between pre and post evaluations in variables under discussion "numerical and engineering skills", and social interaction of the controlling group in favor of the post evaluation. Calculated (T) Value is bigger than (T) Table Value at the significance level 0.05 . 
Table (3)

Differences Significance between both Experimental and Controlling Groups in the Difference between Pre and Post Evaluations for Variables under Discussion

\begin{tabular}{|c|c|c|c|c|c|c|}
\hline \multicolumn{7}{|c|}{$S 1=S 2=30$} \\
\hline \multirow{2}{*}{\multicolumn{2}{|c|}{ Variables }} & \multicolumn{2}{|c|}{ Pre Evaluation } & \multicolumn{2}{|c|}{ Post Evaluation } & \multirow{3}{*}{$\begin{array}{c}\text { Calculated } \\
\text { (T) Value } \\
* 15.594\end{array}$} \\
\hline & & Median & Deviation & Median & Deviation & \\
\hline \multirow{3}{*}{$\begin{array}{c}\text { Achievement } \\
\text { Test }\end{array}$} & Numerical Skills & 8.567 & 1.382 & 5.167 & 1.367 & \\
\hline & Engineering Sills & 7.467 & 1.852 & 2.867 & 1.358 & $* 12.647$ \\
\hline & Total Degree & 16.033 & 2.205 & 8.133 & 1.871 & $* 16.656$ \\
\hline \multicolumn{2}{|c|}{ Social Interaction } & 128.333 & 31.303 & 118.333 & 33.434 & $* 5.706$ \\
\hline
\end{tabular}

(T) Value in the table at $0.05=1.682$

*Function

Table (3) shows the existence of statistically significant differences between both the experimental and controlling groups for the difference between pre and post evaluations for variables under discussion "numerical and engineering skills", and social interaction of the controlling group in favor of the post evaluation. Calculated (T) Value is bigger than (T) Table Value at the significance level 0.05.

\section{Results Discussion:}

Table (1) shows the existence of statistically significant differences between pre and post evaluations in variables under discussion "numerical and engineering skills", and social interaction of the experimental group in favor of the post evaluation. Calculated (T) Value is bigger than (T) Table Value at the significance level 0.05. This is because the child can be learned and educated, and his/her physical and psychological abilities can be developed when being active. Playing is the child's life through which s/he lives and gains self-achievement. During playing, the child does not process things or ideas as they were prepared for $\mathrm{him} / \mathrm{her}$ as s/he rushes in his/her daily moves to express emotions and mainly motivated by eagerness and love to move. Such result agrees with the study results of Othman (1997), Maria (2005), Elsayed (2007), and Zahran (2006) that playing is an essential educational medium that contributes greatly in forming the child in such structural stage of growth. Throughout playing, the child's desire is satisfied and children's learning throughout motor activity is considered the modern attitude of learning beginning. Such activity releases mental concepts and pictures of objects and creatures that the child deals with then $\mathrm{s} / \mathrm{he}$ has a clear vision for spatial relationships that show up throughout motor activity with objects. Also, the child forms a clear vision for characteristics of these objects and creatures (Zahran, 2006).

Also, there are statistically significant differences between pre and post evaluations in the variables under discussion for the experimental group "social interaction" in favor of the post evaluation. Calculated (T) Value is bigger than (T) Table Value at the significance level 0.05. This is due to the movement program under discussion that consists of movement quantity that positively affects the social interaction of children specially the program that consisted of basic movements (transitional motions, non-transitional motions, and processing motions) in addition to small games that require competitive and team work, and cooperation among children. Positively, such process leads to developing social interaction and agrees with study results of Dawoud (2008) and Mohamed (2004). It also agrees with Ronning \& Nabazaka (1993), and Abdelkhalik (2001) who mentioned that games of such stage are considered basic elements since they offer a broad base to develop movement and social abilities that contribute in the process of construction of the child in favor of the society. In addition, they surely contribute in the process of child's social interaction throughout a group 
s/he works in. Playing has a social importance as it is the childlike aspect of the social life interaction. The child learns throughout games rules and systems, and develops corporation among team members besides the spirit of competition (Ronning \& Nabazaka, 1993; Abdelkhalik (2001).

Alkholy \& Ratib (2009) mention that movement activity is one of the main methods for children to learn behavior, and to acquire all attitudes, skills, and values that are appreciated by the society. As a result, education experts consider movement and movement activities as experience and mechanism for social upbringing. Both movement and movement activities are involved in all life aspects since movement exists in almost all vital and social activities (Alkholy \& Ratib, 2009).

Table (2) shows the existence of statistically significant differences between pre and post evaluations in the variables under discussion "numerical and engineering skills, and social interaction" of the controlling group in favor of the post evaluation. Calculated (T) Value is bigger than (T) Table Value at the significance level 0.05 . This is due to the nature of mental growth and maturity, and teaching by depending on pictures. The existence of some movement activities in the kindergarten program helped improving such variables under discussion but slightly compared to children of the experimental group. Also, when the child joins kindergarten, s/he moves from atmosphere of home to a school-like atmosphere where playing dominates and the child's social relations expand to involve class teacher and mates. Since playing is a necessity and a requirement for preschool child, it is the prevailing activity that enhances him/her physically, mentally, psychologically, and socially. This agrees with the study results of Othman (2001), Mohamed (2004), and Elsayed (2007) that referred to the effectiveness of movement education programs for their importance in developing children movement skills, getting those children lots of knowledge, information, and attitudes, and giving them the opportunity to learn.

Kindergarten stage is considered a preliminary stage for the primary stage as the child moves from atmosphere of home to a school-like atmosphere where playing dominates and the child's social relations expand to involve class teacher and mates who form the companion core. During this period, the child learns the simple rules of social relations (Ahmed, 1994; Saber, 2007).

Table (3) shows the existence of statistically significant differences between both the experimental and controlling groups in differences between pre and post evaluations for variables under discussion "numerical and engineering skills" in favor of the experimental group in the post evaluation at the significance level 0.05. This is because movement education program consisted of various and multiple movement activities that motivate children's emotions, feelings, and enthusiasm that increases the effectiveness of the lesson and children's motivation. In addition, child is greatly motivated by the program content of various and chosen small games. This agrees with the study results of Othman (1997), Erk (1999), Mohamed (2002), Rabei (2000), Maria (2005), Elsayed (2006), and Elsayed (2007) that the introduction of creation for successful learning is throughout movement. Moreover, children learn numbers and geometrical shapes throughout movement games. This agrees with what Alkholy (1996) referred to that movement activity program led to the improvement of study skills (Arabic - mathematics) concerning remembering, understanding and applying. The same has been reached by Nader Abbass concerning school skills of English language and mathematics. Also, Alan emphasized the positive relation between movement skill and cognitive learning in mathematics, writing, reading, and language (Al-Kholy, 1996).

Learning by movement exploration has a special importance for young children as they need to understand the world around them and to form concepts about this world throughout direct interaction with objects, observing and exploring their contents. Throughout interaction with nature, the child finds out that different objects may come up with different shapes: circular, square, or triangular. Movement exploration urges the child to create, excel and think to get the information by themselves giving them self-confidence, encouraging them to understand and develop movement as well as giving them the opportunity to explore their 
abilities and potentials (Al-Nashef, 1997; Rabei, 2000; and Ratib, 2009).

There are statistically significant differences between both the experimental and controlling groups in differences between pre and post evaluations for variables under discussion "social interaction" in favor of the experimental group in the post evaluation at the significance level 0.05 . This is because that movement education program is full of various movement games and activities that are prepared for children's interests and desires as well as the characteristics of their ages which give these games and activities elements of excitement, pleasure and happiness for children which leads to increase their effectiveness with connecting with the others and with the social environment. Also, movement activity for child means life, self-exploration, exploring surrounding physical and social environment, freedom, security, connectivity, pleasure, social acceptance. Moreover, movement activity contributes in developing the child socially throughout giving him/her lots of social skills and moral values that leads to his/her social interaction, adaptation, cooperation, and loyalty. This agrees with the study results of Mohamed (2004), Dawoud (2008), and Sherif (20010 that playing contributes in providing the child with social interaction and emotional maturity. Without playing with the others, the child, the child becomes selfish, dominating, narrow-minded, and not loved by the others. Oppositely, if child uses to play with the others, s/he learns how to give and receive, gets rid of self-centralization, and learns how to exchange roles. Throughout giving and receiving, child learns how to accept deaf gracefully as well as gain (Sherif, 2001).

Whitehead (1993) mentions that modern learning depends mainly on the children's feelings of happiness and pleasure and their interests. Good learning does not depend on formal system or the traditional academic methods as the child likes unstressful competition but simple ones that do not consist of formal calls (Whitehead, 1993).

Abdelkarim (1995) agrees with Ivory \& Mccollum (1999) that playing situations lead to make behavior fundamental adjustments that provide children with the opportunities to interact with the others. Playing allow the child to try choices and possible solutions. Simple games of rules and limits provide lots of opportunities for children to learn how to respect the others and the property and to play in a socially accepted way (Abdelkarim, 1995; Ivory \& Mccollum, 1999).

\section{Suggestions:}

1. The proposed program of movement education that was applied on the experimental group contributed in learning some numerical and engineering skills and developing social interaction for children of the research sample.

2. The traditional program that was applied on the controlling group led to a little improvement in learning some numerical and engineering skills and developing social interaction for children of the research sample.

3. The experimental group children surpassed their counterparts in the controlling group in learning some numerical and engineering skills and developing social interaction.

\section{Recommendations:}

1. Applying the proposed program of movement education for its great effect on learning some numerical and engineering skills and developing social interaction for children of Preschool stage.

2. Using preparation curricula for kindergarten female teachers in faculties of Educations and Kindergarten to be specialized in movement education with focusing on the applied section.

3. Taking care of movement activities by using exploring method for its great effect on learning.

4. Setting training courses for preschool female teachers to inform them of what is new in educational systems.

5. Setting academic programs to produce a professional teacher of physical education for preschool and primary stages in the faculties of Physical Education. 


\section{References:}

\section{Arabic References:}

1. Alkholy, Amin Anwar (1996): Principles of Physical and Sports Education (Introduction History - Philosophy). Part One. Cairo. Dar Elfikr Elarabi. p. 163.

2. Alkholy, Amin Anwar \& Ratib, Osama Kamel (2009): Theories and Programs of Movement Education for Children. First Edition, Cairo, Dar Elfikr Elarabi, pp. 30, 31, 259.

3. Elsayed, Eman Fathy (2007): Effect of Educational Program by Using Movement Exploring Activities on Giving Preschool Child Numerical and Engineering Skills. Master's Thesis. Tanta University.

4. Elsayed, Mona Mousa (2006): Effect of Movement Exploration Activity on Giving Numerical and Engineering Skills to Preschool Children. Master's Thesis. Faculty of Physical Education. Tanta University.

5. Elsayed, Fouad Albahey \& Abdelrahman, Saad (1999): Social Psychology: Modern Vision. Cairo. Dar Elfikr Elarabi. pp. 146, 147.

6. Alshamary, Wegdan (2005): Role of the Story in Developing Abilities and Creative Characteristics for Kindergarten Children. Cairo. Dar El Alameya for Publishing. p. 23.

7. El Mosherafy, Insherah Ibrahim (2009): Movement Education for Kindergarten Children, Available online at http://uqu.edu.sa/page/ar/91517. Access on 25/06/2011.

8. Al-Nashef, Huda Ahmed (1997): Strategies of Teaching and Learning in Early Childhood. Second Edition. Dar Elfikr Elarabi. Cairo. p. 237.

9. Ahmed, Zakia Ibrahim (1994): Effectiveness of Using Movement Story on Movement and Linguistic Growth for Preschool Child. Journal of the Faculty of Education. Mansoura University. Issue of 24. January. p. 191.

10. Ahmed, Sohair Kamel (2006): Emotional Education and Psychological Health of the Child. Annual Conference of the Faculty of Kindergarten. Cairo University. p. 52.
11. Dawoud, Demiana Salah (2008): Effectiveness of Program for Employing Songs and Chants in Developing Social Interaction for Kindergarten Child. Master's Thesis. Faculty of Kindergarten. Cairo University.

12. Rabei, Maraam Serag El Din (2000): Effectiveness of Emotive Movement Program by Using Exploration Method on Developing Movement Creativity for Preschool Child. Ph.D. Thesis. Unpublished. Faculty of Physical Education. Tanta University, p. 39.

13. Zahran, Laila Abd El Aziz (2006): Scientific and Technical Principles for Setting Curricula and Programs in Physical Education. Fourth Edition. Cairo. Dar Zahran for Publication and Distribution. p. 167.

14. Sherif, Nadia Mahmoud (2001): Playing as a Dominant Activity in Child's Life, Khotwa Magazine. Thirteenth Issue. Cairo. The Arab Council for Childhood and Development. p. 29.

15. Saber, Fatma Awad (2007): Movement Education and Its Application. Second Edition. Alexandria. Dar Alwafaa for Publishing and Distribution. p. 39.

16. Abdelkhalik, Wafaa Mohamed (2001): Social Roles games and the Relationship with Upbringing the Characteristics of Kindergarten Children. Khotwa Magazine. Thirteenth Issue. Cairo. The Arab Council for Childhood and Development. p. 24.

17. Abd El Fattah, Azza Khalil (1994): Kindergarten, specifications, Construction, Basics, and work Method, Cairo, Dar Elfikr Elarabi.

18. AbdelKarim, Afaf (1995): Movement Program and Teaching for Young Children. Alexandria. Monchaat-Al-Maaref. p. 153.

19. Othman, Mervat Farid (2001): Effect of Proposed Program for Movement education on Movement Abilities and Some Basic Skills. Unpublished Master's Thesis. Faculty of Physical Education for Girls. Helwan University.

20. Othman, Afaf Othman (1997): Effect of Movement Games in Giving Verbal and Numerical Concepts for (3-4 year-old) Children. The International Scientific Conference (Sports and Challenges of 21 st Century). 
21. Othman, Afaf Othman (2008): Modern Attitudes in Movement Education. Alexandria. Dar Alwafaa for Publishing and Distribution. p. 236.

22- Othman, Afaf Othman (2011): Movement Is The Key to Learning. Alexandria. Dar Alwafaa for Publishing and Distribution. p. 61,62.

23. Kenawy, Huda Mohamed (2004): Children and Kindergartens. The Anglo Egyptian Bookshop. Cairo. p. 19.

24. Mohamed, Rashid Amer (2004): Effect of Proposed Movement Education Program on Developing Some Basic Movement Skills and Physical Abilities, and their Relationship with the Level of Movement Cognitive Ability for (5-6-year-old) Preschool Children. Academic Journal for Physical and Sports Education Sciences. Faculty of Physical Education. Mansoura University. Issue (2). March.

25. Mohamed, Nebras Younos (2004): Effect of Using Programs of Movement Games and Social and Mixed Games in Developing Social Interaction for (5-6-year-old) Kindergarten Children. Ph.D. Thesis. Faculty of Physical Education. University of Mosul. p. 15.

26. Mohamed, Huda Nour El Din (2002): Effect of Movement Education Lesson on Learning in Preschool. Faculty of Physical Education for Girls. Helwan University.

27. Haikal, Mohamed Atef (2010): Effect of Educational Program by Using Multimedia on some Basic Movement Skills for Kindergarten Children. Master's Thesis. Faculty of Physical Education. Mansoura University. p. 2.

\section{Foreign References:}

28. Ivory, J. \& Mccollum, J. (1999): Effect of Social and Isolate Toys on Social Play in an Inclusive setting. Journal of Special Education. Vol. (4). No. (32), p. 238.

29. Erk, K. (1999): Evaluation Der Effektivitat Eines Bewegung Sforder Programmes in Kindergarten. Diplomarbeit Deutsche Hochschule Koln.

30. Maria, E. (2005): Preschool Physical Education: A Case Study of the Factors That Influence Movement Instruction to Preschool Children. Ph.D., United States, Florida.

31. Ohuruogu Ben, Orji Scholastica (2008): The Role of Movement Education in Children's Play Developments. Fourth International Council for Health, Physical Education, Recreation, Sport and Dance (ICHPER-SD) Africa Regional Congress, 14017 October, p. 317.

32. Ronning, J., Nebuzoka, D. (1993): Promoting Social Interaction and Status of Children with Intellectual Disabilities in Zambia Journal of Special education. Vol. 27. No. (3), p. 88.

33. Whitehead, M. (1993): Why Not Happiness on Change and Conflict in Early Education. New York. Vintage Book. p. 150. 